\title{
PELAKSANAAN ASUHAN KEPERAWATAN TERHADAP PASIEN DEHIDRASI
}

\author{
Ade Sulistya Lubis/181101121 \\ adesulistyalubis@gmail.com
}

\begin{abstract}
Abstrak
Latar belakang: Dehidrasi merupakan kondisi kekurangan cairan yang keluar lebih banyak daripada jumlah cairan yang masuk. Asuhan keperawatan adalah suatu pendekatan untuk pemecahan masalah yang memampukan perawat untuk mengatur dan memberikan asuhan keperawatan

Tujuan: Untuk dapat mengetahui bagaimana Pelaksanaan asuhan keperawatan terhadap pasien dehidrasiMetode: menggunakan metode tersearch dan analisis dari berbagai sumber seperti buku teks, buku referensi jurnal, e-book. Hasil: Dehidrasi adalah gangguan keseimbangan cairan atau air pada tubuh. Penyebabnya adalah pengeluaran air/cairan lebih banyak daripada pemasukan (melalui minum).Kesimpulan: Dehidrasi adalah kehilangan cairan dari keseluruhan kompartemen tubuh. Dehidrasi disebabkan karena kebutuhan cairan lebih banyak dari asupan yang mengakibatkan volume cairan dalam darah berkurang
\end{abstract}

Kata kunci:Pelaksanaan, Asuhan Keperawatan, Dehidrasi

\begin{abstract}
Background: Dehydration is a condition of lack of more fluid coming out than the amount of fluid that enters. Nursing care is an approach to problem solving that enables nurses to organize and provide nursing care. Objective: To be able to find out how the implementation of nursing care for dehydrated patients. Method: uses the search method and analysis from various sources such as textbooks, journal reference books, e-books. Result: Dehydration is a disorder of the balance of fluid or water in the body. The reason is spending more water / fluid than intake (through drinking). Conclusion: Dehydration is the loss of fluids from the whole compartment of the body. Dehydration is caused by the need for more fluid than intake which results in reduced fluid volume in the blood.
\end{abstract}

Keywords: Implementation, Nursing, Dehydration 
PENDAHULUAN

\section{LATAR BELAKANG}

Penurunan asupan cairan dapat terjadi pada pasien yang sedikit mengkonsumsi cairan tanpa mereka sadari bahwa mereka kehilangan cairan tubuh yang dapat membahaykan tubuh mereka. Kehilangan cairan yang tidak diimbangi dengan kehilangan elektrolit dalam jumlah proposional, terutama natrium dapat mengakibatkan dehidrasi (Triyana, 2012).

Dehidrasi diartikan sebagai kurangnya cairan di dalam tubuh karena jumlah yang keluar lebih besar dari pada jumlah yang masuk. Jika tubuh kehilangan banyak cairan, maka tubuh akan mengalami dehidrasi (Rismayanthi, 2012). Bahaya dehidrasi diantaranya adalah penurunan kemampuan kognitif karena sulit berkonsentrasi, risiko infeksi saluran kemih dan terbentuknya batu ginjal. Konsumsi cairan dalam jumlah yang cukup dan tidak menahan air kemih adalah cara yang paling efektif untuk mencegah infeksi saluran kemih, serta menurunnya stamina dan produktivitas kerja melalui gangguan sakit kepala, lesu, kejang hingga pingsan. Kehilangan cairan lebih dari 15\% akan berakibat fatal (Alim, 2012).
Salah satu pelayanan kesehatan yang diberikan oleh tenaga kesehatan adalah pelayanan keperawatan, Sebagai bagian dari pelayanan kesehatan, maka pelayanan keperawatan yang dilakukan oleh tenaga perawat memiliki tugas diantaranya memberikan asuhan keperawatan (Hidayat, 2011, p.75).

Asuhan keperawatan adalah suatu pendekatan untuk pemecahan masalah yang memampukan perawat untuk mengatur dan memberikan asuhan keperawatan. Standar asuhan yang tercantum dalam Standar Praktik Klinis Keperawatan terdiri dari lima fase asuhan keperawatan: 1) Pengkajian; 2) Diagnosa; 3) Perencanaan; 4) Implementasi; dan 5) Evaluasi. Salah satu manfaat dari penerapan asuhan keperawatan yang baik adalah meningkatkan mutu dan kualitas pelayanan dalam bidang keperawatan (Kozier, 2010).

\section{TUJUAN}

Tujuan pembandigan dari beberapa jurnal dan sumber lainnya agar dapat mengetahui bagaimana Pelaksanaan asuhan keperawatan terhadap pasien dehidrasi. 


\section{METODE}

Jurnal ini menggunakan metode tersearch dan analisis dari berbagai sumber seperti buku teks, buku referensi jurnal, ebook. Dari analisi berbagai sumber digunakan Untuk mengetahui bagagaimana Pelaksanaan asuhan keperawatan terhadap pasien dehidrasi. Penulisan jurnal ini dimulai pada tanggal 10 november 2019. Pengolahan jurnal dilakukan dengan metode membandingkan beberapa jurnal yang berhubungan dengan Pelaksanaan asuhan keperawatan terhadap pasien dehidrasi.

\section{HASIL}

Dehidrasi adalah gangguan keseimbangan cairan atau air pada tubuh. Penyebabnya adalah pengeluaran air/cairan lebih banyak daripada pemasukan (melalui minum). Dehidrasi lebih mudah terjadi pada anak-anak dan wanita karena di dalam tubuhnya banyak mengandung lemak yang hanya mengandung 20\% air. Pada manula juga sering terjadi dehidrasi karena kadar air dalam tubuhnya menurun akibat penuaan organ-organ tubuh. Selain faktor kondisi tubuh, dehidrasi umumnya lebih mudah terjadi pada orang yang memiliki banyak aktivitas seperti remaja atau atlet olahraga dengan porsi latihan besar.

Dehidrasi dapat memberikan pengaruh yang signifikan bagi tubuh, hal ini terjadi pada: kehilangan cairan $2 \%$ dari total berat badan dapat memberikan efek penurunan performa, tubuh menjadi lemas, lemah, dan berkurangnya konsentrasi. Saat dehidrasi mencapai 4\%, kapasitas kerja otot menurun; 5\%, tubuh mengalami heat exhaustion (Keletihan yang dialami tubuh yang disebabkab karenan hilangnya cairan); 7\%, dapat menyebabkan terjadinya halusinasi akibat otak mulai terlalu 'panas' dan kerjanya menjadi tidak terkontrol; $10 \%$, terjadi heat stroke (keadaan dimana suhu tubuh terlalu tinggi dan kerja organ tubuh menjadi kacau). Rasa haus dan bibir kering merupakan indikasi dehidrasi yang terlambat. Oleh karena itu, sebaiknya atlet minum tidak hanya saat atlet merasa haus (Kraemer, dkk, 2012: 235).

\section{PEMBAHASAN}

Dehidrasi merupakan ketidakseimbangan cairan tubuh dikarenakan pengeluaran cairan lebih besar daripada pemasukan (Almatsier, 2009). Dehidrasi dapat terjadi tanpa 
disadari di saat melakukan aktivitas dan juga karena cuaca panas (D'anci et al., 2009). Dehidrasi juga dapat terjadi karena kurangnya konsumsi cairan dan konsumsi obat diuretik (Schwabe et al., 2007).

Dehidrasi adalah kehilangan cairan dari keseluruhan kompartemen tubuh. Dehidrasi disebabkan karena kebutuhan cairan lebih banyak dari asupan yang mengakibatkan volume cairan dalam darah berkurang. (Guyton, 2012). Seseorang dikatakan dehidrasi ringan (cairan tubuh berkurang 1-3\%) bila mengalami gejala-gejala seperti keringnya mukosa, turgor kulit menurun, lesu, gelisah, mata cekung urin keruh, menurunnya tekanan darah, hingga gejala gangguan fisik, psikologis, suasana hati (mood), dan gangguan fungsi kognitif (David Benton, 2011, Kemenkes, 2011).

\section{Tanda-tanda dehidrasi}

1. Dehidrasi hipertonik ditandai dengan tingginya kadar natrium serum (lebih dari $145 \mathrm{mEq} / \mathrm{L}$ ) dan peningkatan osmolalitas efektif serum (lebih dan $285 \mathrm{mosmol} / \mathrm{liter}$ ).

2. Dehidrasi isotonik ditandai dengan normalnya kadar natrium serum (135$145 \mathrm{mEq} / \mathrm{L})$ dan osmolalitas efektif serum (270-285 mosmol/liter).
3. Dehidrasi hipotonik ditandai dengan rendahnya kadar natrium serum (kurang dari $135 \mathrm{mq} / \mathrm{L}$ ) dan osmolalitas efektif serum (kurang dari $270 \mathrm{mosmol} /$ liter)

\section{Klasifikasi Dehidrasi}

1. Tanpadehidrasi

2. Dehidrasi ringan/sedang

3. Dehidrasi berat

\section{Bermacam-macam penyebab dehidrasi} menentukan tipe/jenis-jenis dehidrasi

1. Dehidrasi

Perdarahan, Muntah, Diare, Hipersalivasi, Fistula, Ileustomy (pemotongan usus), Diaporesis (keringat bedebihan), Luka bakar, Puasa, Terapi hipotonik, Suction gastrointestinal (cuci lambung).

2. Dehidrasi hipotonik

Penyakit DM, Rehidrasi cairan berlebih, Malnutrisi berat dan kronis

3. Dehidrasi hipertonik

Hiperventilasi, Diare air, Diabetes Insipedus ( hormon ADH menurun ), Rehidrasi cairan berlebihan, Disfagia, Gangguan rasa haus, kesadaran, Infeksi sistemik : suhu tubuh meningkat. 


\section{PENUTUPAN}

\section{KESIMPULAN}

Unutuk melaksanakan Asuhan keperawatan pada pasien dehidrasi dapat melakukan tindakan pemecahan masalah yang memampukan perawat untuk mengatur dan memberikan asuhan keperawatan kepada pasien. Yang di sebabkan karena kebutuhan cairan lebih banyak dari asupan yang mengakibatkan volume cairan dalam darah berkurang.

\section{SARAN}

Untuk melaksanakan asuhan keperawatan kepada pasien dehidrasi perawat di sarankan untuk mengetahui apa saja yang dilakukan terhadap pasien dehidrasi.

\section{REFERENSI}

Asmadi. 2008. Konsep Dasar Keperawatan. Jakarta : EGC

Asmuji. 2012. Manajemen Keperawatan Konsep dan Aplikasi. Jogjakarta: Ar-Ruzz Media. Haryanto. 2007. Konsep Dasar Keperawatan dengan Pemetaan Konsep. Jakarta : Salemba medika.
Hidayat, A. A. A. (2002). Pengantar dokumentasi proses keperawatan. Jakarta:EGC.

Kemenkes RI. (2015). Profil Kesehatan Indonesia Tahun 2014. Jakarta..

Kozier, Barbara. (2010). Buku Ajar Fundamental Keperawatan; Konsep, Proses dan Praktik edisi 7 Volume. Jakarta: EGC.

Modric J. Dehydration types: Pathophysiology, lab test and values. eHealthstar .2013 July 31 .

Nurarif .A.H. dan Kusuma. H. (2015). APLIKASI Asuhan Keperawatan Berdasarkan Diagnosa Medis \& NANDA NIC-NOC. Jogjakarta : MediAction..

Nursalam. (2011). Manajemen Keperawatan. Edisi 3. Salemba medika;287-94.

Rohmah, N.Integrasi proses keperawatan dalam pembelajaran klinik keperawatan one to one teaching and feed back. Vol. 1, No. 1, Desember 2010: The Indonesian Journal Of Health Science

Rohmah, N. dan Walid, S. (2009). Proses keperawatan, teori dan aplikasi dilengkapi dengan petunjuk praktis penyususnan proses 
keperawatan dan dokumentasi

NANDA-NOCNIC. Arrus Media

Jogjakarta.

Price, Sylvia A dan Lorraine M Wilson.

(1995). Patofisiologi Konsep

Kllinis Proses-proses Penyakit.

Edisi 4. Jakarta : EGC

Potter, P. A \&Perry, A. G. (2005). Buku

Ajar Fundamental

Keperawatan.Jakarta: EGC.

Potter \& Perry. (2009). Fundamental of Nursing. 7 th Ed. St Louis Missouri: Elseiver

Perry, A. G., \& Potter, P. A. (2009). Potter and perry's fundamentals of nursing Australian version. ( $\mathrm{J}$. Crips \& C. Taylor, Eds.) ( $3^{\text {rd }}$ ed). Australian : mosby Elsevier Australia.

Potter, P.A.,\& Perry, G.A. (2010). Fundamental of nursing (Volume 2, 7th Ed.). ST. Louis: Mosby Year Book.

Potter, P. A., \& Perry, A. G., (2013). Fundamentals of nursing. ( $\left.8^{\text {th }} \mathrm{ed}\right)$. Elsevier.

Smeltzer, Suzanne C dan Brenda G Bare. (2001). Buku Ajar Keperawatan Medikal Bedah Brunner \& Suddarth. Edisi 8. Jakarta :EGC
Suyono, Slamet. (2001). Buku Ajar Ilmu

Penyakit Dalam. Edisi 3. Jilid I II. Jakarta.: Balai Penerbit FKUI

Simamora, R. H. (2019). Menjadi Perawat yang: CIH'HUY. Surakarta: Kekata Publisher.

Simamora, Roymond H. 2010. Komunikasi dalam Keperawatan, Ed 1 hal 210. Jember: Univesity Press.

Simamora, Roymond H. Dokumentasi Proses Keperawatan, 'Ed 1 hal 144. Jember: University Press.

Simamora, Roymond H. 2008. Peran Manajer dalam Pembinaan Etika Perawat Pelakasanaan dalam Peningkatan Kualitas Pelayanan Asuhan Keperawatan: Jurnal IKESMA, Ed 4, 2. 